\title{
CENTRAL NERVOUS SYSTEM ABNORMALITIES ON MIDLINE FACIAL DEFECTS WITH HYPERTELORISM DETECTED BY MAGNETIC RESONANCE IMAGE AND COMPUTED TOMOGRAPHY
}

\author{
Vera Lúcia Gil-da-Silva-Lopes', Silvio David Araújo Giffoni²
}

\begin{abstract}
The aim of this study were to describe and to compare structural central nervous system (CNS) anomalies detected by magnetic resonance image (MRI) and computed tomography (CT) in individuals affected by midline facial defects with hypertelorism (MFDH) isolated or associated with multiple congenital anomalies (MCA). The investigation protocol included dysmorphological examination, skull and facial $X$-rays, brain CT and/or MRI. We studied 24 individuals, 12 of them had an isolated form (Group I) and the others, MCA with unknown etiology (Group II). There was no significative diffe ence between Group I and II and the results are presented in set. In addition to the several CNS anomalies previously described, MRI $(n=18)$ was useful for detection of neuronal migration errors. These data suggested that structural CNS anomalies and MFDH seem to have an intrinsic embryological relationship, which should be taken in account during the clinical follow-up.
\end{abstract}

KEY WORDS: frontonasal dysplasia, hypertelorism, midline, craniofacial abnormalities, facial clefts, CNS abnormalities, magnetic resonance image.

\begin{abstract}
Anomalias de sistema nervoso central em defeitos de linha média facial com hipertelorismo detectados por ressonância magnética e tomografia computadorizada

RESUMO - Este estudo objetivou descrever e comparar as anomalias estruturais do sistema nervoso central (SNC) detectadas por meio de ressonância magnética (RM) e tomografia computadorizada (TC) de crânio em indivíduos com defeitos de linha média facial com hipertelorismo (DLMFH) isolados ou associados a anomalias congênitas múltiplas (ACM). O protocolo de investigação incluiu exame dismorfológico, RX de crânio e face, CT e RM de crânio. Foram estudados 24 indivíduos, sendo que 12 apresentavam a forma isolada (Grupo I) e os demais, DLMFH com ACM de etiologia não esclarecida (Grupo II). Não houve diferença en tre os dois grupos e os resultados foram agrupados. Além de várias anomalias de SNC já descritas, a RM foi útil para detecção de erros de migração neuronal. Os dados sugerem que as alterações estruturais de SNC e os DLMFH têm relação embriológica, o que deve ser levado em conta durante o seguimento clínico.
\end{abstract}

PALAVRAS-CHAVE: displasia frontonasal, hipertelorismo, linha média, malformações craniofaciais, fendas faciais, malformações do SNC, ressonância magnética.

Midline facial defects with hypertelorism (MFDH) is a rare group of disorders characterized by ocular hy pe rtelorism and anomalies of frontonasal process. Its isolated form is commonly called frontonasal dysplasia and it is also detected in several conditions of multiple congenital anomalies (MCA) ${ }^{1-3}$. Its pathogenesis is related to a failure during the development of the nasal capsula ${ }^{4,5}$. Differential diagnosis should be done from some conditions which could lead to a similar appearance, such as frontal lipoma and encephalocele $^{5}$. Several structural abnormalities of central nerv- ous system (CNS) are often described in this group, such as encephalocele, myelomeningocele, Chiari's m a I fo rmation and hydrocephalus ${ }^{6}$. Corpus callosum anomalies are reported by several authors ${ }^{3,7-10}$.

Some important points should be mentioned about the MFDH and CNS anomalies. One of them is the rarity and heterogeneity of this condition, which led to isolated descriptions by diffe rent specialties and with diff e rent emphasis. Another one is the advance of neuro rradiology techniques that now allow an excellent evaluation of CNS. The use of magnet-

Departamento de Genética Médica, Faculdade de Ciências Médicas / Universidade Estadual de Campinas, Campinas SP, Brasil (FCM/UNICAMP): ${ }^{1}$ P rofessor Associado, Departamento de Genética Médica; ${ }^{2}$ Doutor em Ciências Médicas com área de concentração em Genética.

Received 24 February 2006, received in final form 21 June 2006. Accepted 27 July 2006.

Dra. Vera Lúcia Gil-da-Silva-Lopes - Departamento de Genética Médica - FCM / UNICAMP - Caixa Postal 6111 - $13084-971$ Campinas SP - Brasil. E-mail: vlopes@fcm.unicamp.br 
ic resonance image (MRI) searching CNS anomalies in a large group of individuals with MFDH has not been reported before.

In this article, we describe the neurorradiological data from 24 patients with MFDH.

\section{METHOD}

The casuistry was composed by 24 individuals ( $8 \mathrm{male}$ and 16 female) affected by MFDH ${ }^{10}$. All of them were previously evaluated by the same clinical geneticist at Hospital das Clínicas HC/ UNICAMP (Campinas, SP, Brasil). They were selected based upon minimum inclusion criteria, which were ocular hypertelorism and frontonasal process anomalies. Twelve individuals presented an isolated form (Group I) and the others, facial findings were part of a multiple congenital anomalies condition with unknown etiology (MCA) (Group II). The average age was 12.57 years.

The investigation protocol included dysmorphological evaluation, skull and facial X-rays, computed tomography (CT) of brain and magnetic resonance image. Six individuals who had metallic clips on their faces were evaluated just by CT.
Brain CT was performed with parallel slices to the inferior orbitomeatal line with $3 \mathrm{~mm}$ of thickness and $5 \mathrm{~mm}$ of space on the posterior fossa. On the supratentorial fossa, the slices had $10 \mathrm{~mm}$ of thickness and space from vertex of transversalis axis.

CNS MRI was performed without contrast at $2.0 \mathrm{~T}$. The sequence was: Axial FSE double eco T2; TE=16/128. TR of $4600,6 \mathrm{~mm}$ of thickness and $2 \%$ of space. Axial FSE double eco $D P, T E=16 / 128$. TR $=4600,6 \mathrm{~mm}$ of thickness and $2 \%$ of space. Sagittal SE T1; TE=10. TR=550, $4 \mathrm{~mm}$ of thickness and space of $0 \%$. Axial SE T1; TE $=10$. TR=550, $6 \mathrm{~mm}$ of thickness and $2 \%$ of space. Coronal SE T1; TE $=10 . T R=550,6 \mathrm{~mm}$ of thickness and $2 \%$ of space. Axial flair inverse recover $T E=90$ on CSF. TR=8100, $\mathrm{Tl}=2200,6 \mathrm{~mm}$ of thickness and $2 \%$ of space. When necessary, CT scan and MRI were performed with anesthesia, according to the American College of Emergency Physicians. The statistics evaluation was perfo rmed by SAS System for Windows (statistical analysis system), version 8.02. It was used Fischer 's exact test (FET). The rejection level was fixed at $5 \%{ }^{11,12}$.

This study was approved by the Ethics Committee of the University Hospital / UNICAMP (n.057/99) and all individuals consented for their inclusion.

Table 1. General aspects and extra- facial features of individuals affected by MFDH in this study.

\begin{tabular}{|c|c|c|c|c|}
\hline & Patient & Sex & Age & Clinical features \\
\hline \multirow[t]{12}{*}{ Group I } & 1 & $\mathrm{M}$ & $16 y$ & Clinodactyly of $5^{\text {th }}$ (hands), hypoplasia of $5^{\text {th }}$ toes \\
\hline & 2 & $\mathrm{~F}$ & $14 y$ & Clinodactyly of $5^{\text {th }}$ (hands) \\
\hline & 3 & $\mathrm{~F}$ & $13 y$ & Prominent sternum, scoliosis \\
\hline & 4 & $\mathrm{~F}$ & $1 y^{2 / 12}$ & Planus foot, overlapping of $2^{\text {nd }}$ to the $3^{\text {rd }}$ toes \\
\hline & 5 & M & $6 y$ & $\begin{array}{l}\text { Over than } 6 \text { whorls in hands, metacarpeal hypoplasia, unilateral } \\
\text { criptorchidism, increased halux- } 2^{\text {nd }} \text { toes. }\end{array}$ \\
\hline & 6 & $\mathrm{~F}$ & $14 y$ & Over than 6 whorls in hands, metacarpeal hypoplasia \\
\hline & 7 & M & $29 y$ & None \\
\hline & 8 & M & $9 y$ & Scoliosis \\
\hline & 9 & $\mathrm{~F}$ & $6 y$ & Over than 6 whorls in hands \\
\hline & 10 & $\mathrm{~F}$ & $16 y$ & Cubitus valgus \\
\hline & 11 & M & $10 y$ & None \\
\hline & 12 & $\mathrm{~F}$ & $2 y^{3 / 12}$ & None \\
\hline \multirow[t]{12}{*}{ Group II } & 13 & $\mathrm{~F}$ & $5 y$ & $\begin{array}{l}\text { Overlapping of } 2^{\text {nd }} \text { toes, wide gap between } 1^{\text {st }} \text { and } 2^{\text {nd }} \text { toes, longitudinal } \\
\text { plantar crease, anteriorized anus, rugose labia majora }\end{array}$ \\
\hline & 14 & $\mathrm{~F}$ & $2 y^{7 / 12}$ & Sacral dimple, clinodactyly of $5^{\text {th }}$ fingers, anteriorized anus \\
\hline & 15 & $\mathrm{~F}$ & $1 y^{6 / 12}$ & $\begin{array}{l}\text { Prominent sternum, sacral dimple, diastasis of abdominal muscles, } \\
\text { umbilical hernia, unilateral ectrodactyly, unilateral post-axial } \\
\text { polidactyly, hisurtism }\end{array}$ \\
\hline & 16 & $\mathrm{~F}$ & $2 y^{8 / 12}$ & Dimples on upper and lower limbs lymphoedema \\
\hline & 17 & M & $7 y$ & $\begin{array}{l}\text { Pectus excavatum, scoliosis, umbilical and inguinal hernia, short } \\
\text { metacarpal, pes planus, peno-scrotal inversion, cryptorchidism }\end{array}$ \\
\hline & 18 & M & $7 y$ & Pectus excavatum, scoliosis \\
\hline & 19 & $\mathrm{~F}$ & $10 y$ & Pectus excavatum, scoliosis, inguinal hernia \\
\hline & 20 & $\mathrm{~F}$ & $24 y$ & Scoliosis, lordosis, hypoplastic labia majora \\
\hline & 21 & $\mathrm{~F}$ & $11 \mathrm{~m}$ & $\begin{array}{l}\text { Shortned lower limbs, anteriorized anus, hypoplastic labia minora, } \\
\text { hisurtism }\end{array}$ \\
\hline & 22 & $\mathrm{~F}$ & $11 \mathrm{~m}$ & $\begin{array}{l}\text { Clinodactyly of } 5^{\text {th }} \text { finger, shortned lower limbs, anteriorized anus, } \\
\text { hypoplastic labia minora }\end{array}$ \\
\hline & 23 & $\mathrm{~F}$ & $11 \mathrm{y}$ & $\begin{array}{l}\text { Pectus excavatum, hipolastic and inverted nipples, kyphosis, } \\
\text { short metacarpal, pes planus }\end{array}$ \\
\hline & 24 & M & $30 y$ & Camptdactyly, wide gap between $1^{\text {st }}$ and $2^{\text {nd }}$ toes \\
\hline
\end{tabular}




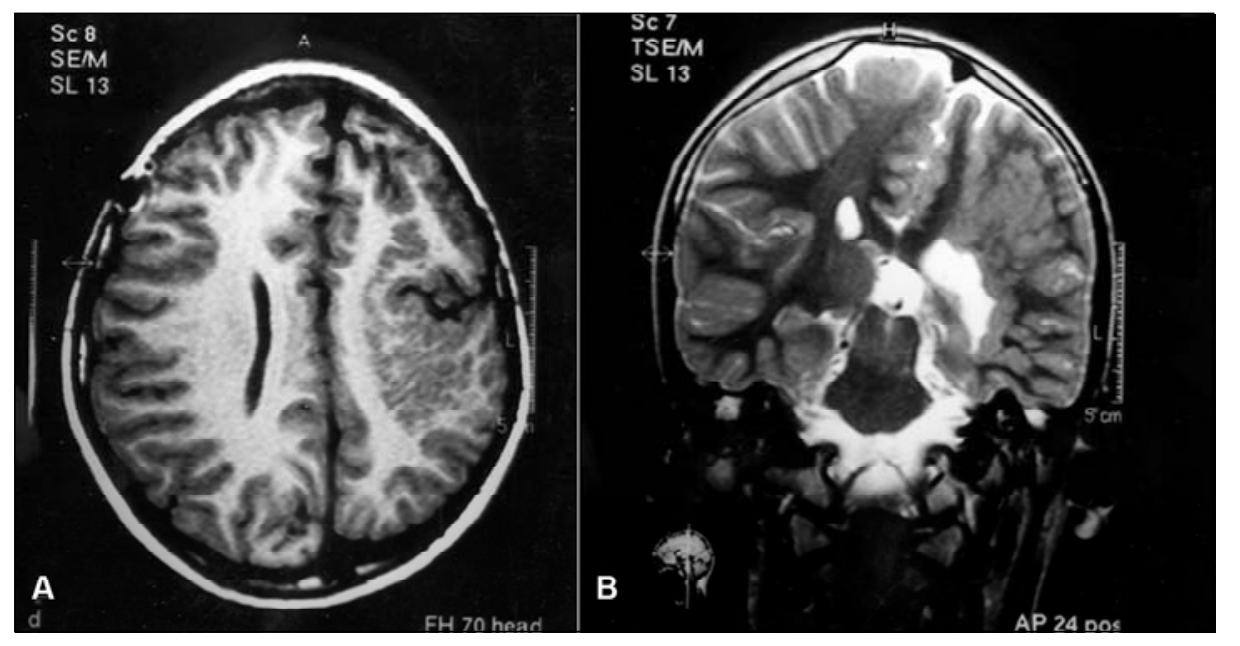

Fig $1 A$ and $B$. MRI shows ence phalic asymmetry, hypoplasia of corpus callosum, gliosis, frontal perisylvian polymycrogiria and heterotopy of gray matter at left hemisphere.

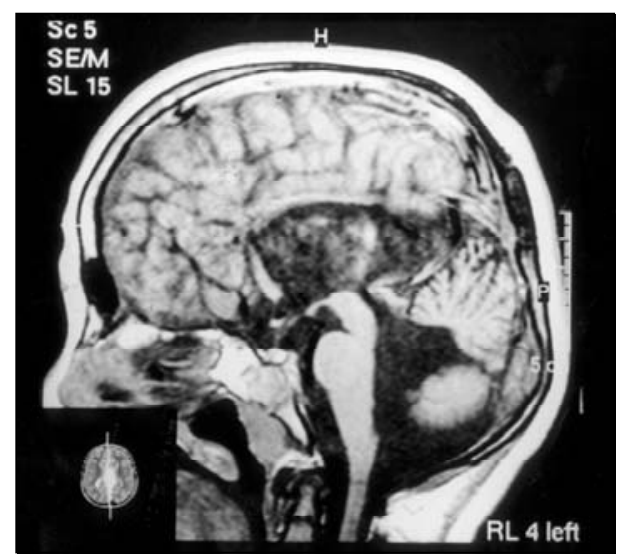

Fig 2. MRI shows frontal encephalocele, corpus callosum dysgenesis and hypoplasia of cerebe lar vermis.

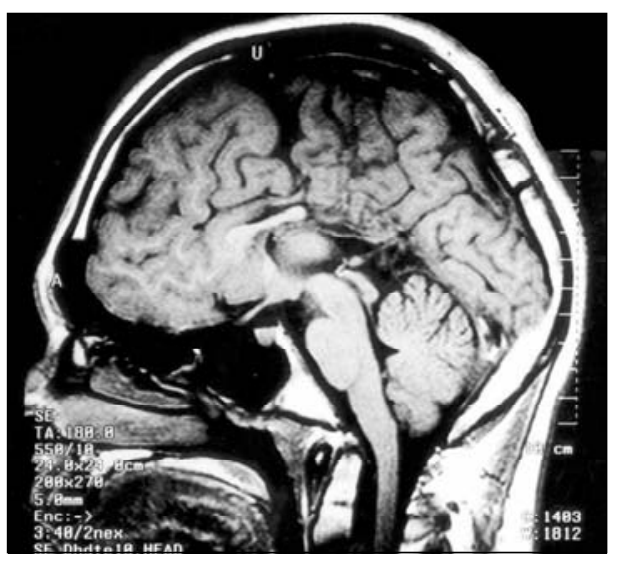

Fig 3. MRI shows mycropoligiria, parietal het erotopy of white matter, corpus callosum dys genesis, squizencephaly.

\section{RESULTS}

Mainly clinical features of Group II are described on Table 1. A considerable heterogeneity of CNS anomalies was detected (Figs $1 \mathrm{~A}$ and $1 \mathrm{~B} ; 2$ and 3 ). Comparing the investigation of Groups I and II, no statistical diffe rence was found and the results are described on Table 2.

\section{DISCUSSION}

Considering the rarity of the condition and the description by different specialties, the evaluation of CNS defects in a significant casuistry with MRI had not been perf o rmed before. Until now, the most part of information about the neurological anomalies in MFDH was obtained using $\mathrm{CT}^{3,7-9}$. These studies showed a large range of CNS anomalies, especially of the corpus callosum, such as lipoma, calcification, and dysgenesis. Some other anomalies were also mentioned, such as encephalic asymmetry and encephalo- cele. In this casuistry, the main defects detected by skull and facial X-rays were hyperteleorbitism (24/24), anterior cranium bifidum (8/24) and frontal osseous failure (4/24). These findings are similar to those previously described.

Guion-Almeida ${ }^{9}$, reviewing 27 patients from the literature and personal cases, re p o rted anterior cranium bifidum in 12 individuals. Gil-da-Silva-Lopes and Maciel-Guerra ${ }^{3}$, evaluating brain CT of 29 personal patients with MFDH, including isolated form and those with multiple congenital anomalies with unknown etiology, detected anterior cranium bifidum in 6 individuals and frontal osseous failure in 4.

Brain CT in this study showed anomalies of corpus callosum (8/21) and several defects, such as osseous (7/21), ventricular (3/21), cortical (2/21), frontal lobe atrophies (2/21) and encephaloceles (3/21). Lipoma of corpus callosum, a usual feature reported, was detected in just one of our patients. Corpus callosum 
Table 2. Radiological findings of individuals affected by MFDH in this study.

\begin{tabular}{|c|c|c|c|c|}
\hline & Patient & Skull and facial X-rays & CT scan & MRI \\
\hline \multirow[t]{12}{*}{ Group I } & 1 & Hyperteleorbitism & $\begin{array}{l}\text { Encephalic and ventricular asymmetry, } \\
\text { corpus callosum dysgenesis }\end{array}$ & $\begin{array}{l}\text { Corpus callosum agenesis, colpocephaly, } \\
\text { colpocephaly, neuronal migration errors }\end{array}$ \\
\hline & 2 & Hyperteleorbitism & Polips of paranasasal sinus & Normal \\
\hline & 3 & $\begin{array}{l}\text { Hyperteleorbitism, } \\
\text { anterior bifid cranium, } \\
\text { median maxilar cleft }\end{array}$ & $\begin{array}{l}\text { Abnormal thickness of ethmoidal, } \\
\text { vomeris and cribriform lamina, } \\
\text { possible ethmoidal encephalocele }\end{array}$ & Nodular heterotopia areas \\
\hline & 4 & Hyperteleorbitism & $\begin{array}{l}\text { Fronto-parietal atrophy, } \\
\text { ventricular enlargement }\end{array}$ & I \\
\hline & 5 & Hyperteleorbitism & $\begin{array}{l}\text { Right parietal porencephaly, } \\
\text { ventricular dilatation }\end{array}$ & $\begin{array}{l}\text { Corpus callosum dysgenesis, frontal } \\
\text { micropoligiria }\end{array}$ \\
\hline & 6 & $\begin{array}{l}\text { Hyperteleorbitism, } \\
\text { anterior bifid cranium, } \\
\text { median nasal cleft }\end{array}$ & Sphenoidal hyperostosis & $\begin{array}{l}\text { Chiari's anomaly, enlargement } \\
\text { of } 4^{\circ} \text { ventricle }\end{array}$ \\
\hline & 7 & $\begin{array}{l}\text { Hyperteleorbitism, } \\
\text { anterior bifid cranium }\end{array}$ & Normal & I \\
\hline & 8 & $\begin{array}{l}\text { Hyperteleorbitism, } \\
\text { anterior bifid cranium }\end{array}$ & I & $\begin{array}{l}\text { Corpus callosum dysgenesis, cerebellar } \\
\text { dysgenesis, Dandy-Walker anomaly, } \\
\text { nodular heterotopia areas }\end{array}$ \\
\hline & 9 & $\begin{array}{l}\text { Hyperteleorbitism, } \\
\text { anterior bifid cranium, } \\
\text { partial frontal aplasia }\end{array}$ & $\begin{array}{l}\text { Corpus callosum dysgenesis, } \\
\text { Tessier (0-14) cleft, auditive } \\
\text { channel agenesis }\end{array}$ & I \\
\hline & 10 & $\begin{array}{l}\text { Hyperteleorbitism, } \\
\text { partial frontal aplasia }\end{array}$ & $\begin{array}{l}\text { Lipoma of corpus callosum, } \\
\text { ethmoidal encephalocele }\end{array}$ & I \\
\hline & 11 & Hyperteleorbitism & Normal & $\begin{array}{l}\text { Nodular heterotopia at left } \\
\text { hemispherium, frontal and perisilvian } \\
\text { micropoligiria, corpus callosum } \\
\text { dysgenesis, cerebellar asymmetry }\end{array}$ \\
\hline & 12 & Hyperteleorbitism & Normal & Normal \\
\hline \multirow[t]{12}{*}{ Group II } & 13 & Hyperteleorbitism & Corpus callosum dysgenesis & $\begin{array}{l}\text { Nodular heterotopia at frontal left } \\
\text { lobe, corpus callosum agenesis, } \\
\text { cerebellar asymmetry }\end{array}$ \\
\hline & 14 & Hyperteleorbitism & Normal & Normal \\
\hline & 15 & Hyperteleorbitism & Atrophy signs at frontal lobes & I \\
\hline & 16 & $\begin{array}{l}\text { Hyperteleorbitism, } \\
\text { anterior bifid cranium }\end{array}$ & Asymmetry and dilatation of ventricles & $\begin{array}{l}\text { Cortical displasia at frontal poles, } \\
\text { enlargement of } 3^{\circ} \text { and } 4^{\circ} \text { ventricle }\end{array}$ \\
\hline & 17 & $\begin{array}{l}\text { Hyperteleorbitism, } \\
\text { anterior bifid cranium }\end{array}$ & Corpus callosum agenesis & Corpus callosum dysgenesis, pineal cyst \\
\hline & 18 & Hyperteleorbitism & Normal & Thin cervical marrow \\
\hline & 19 & $\begin{array}{l}\text { Hyperteleorbitism, } \\
\text { asymmetric skull }\end{array}$ & $\begin{array}{l}\text { Asymmetric skull, corpus callosum } \\
\text { dysgenesis }\end{array}$ & $\begin{array}{l}\text { Corpus callosum dysgenesis, cranium } \\
\text { deformity that takes to tentorium } \\
\text { verticalization, hemispheres and } \\
\text { cerebellar lobes reduction }\end{array}$ \\
\hline & 20 & Hyperteleorbitism & I & $\begin{array}{l}\text { Vascular spaces enlargement in the } \\
\text { topography of the basis nucleus }\end{array}$ \\
\hline & 21 & Hyperteleorbitism & Normal & Normal \\
\hline & 22 & $\begin{array}{l}\text { Hyperteleorbitism, } \\
\text { anterior bifid cranium }\end{array}$ & $\begin{array}{l}\text { Fissure at posterior portion of } \\
\text { corpus callosum, frontal encephalocele, } \\
\text { ventricular system malformation, } \\
\text { cerebellar vermis hypoplasia, gray } \\
\text { substance ectopic of frontal left lobe }\end{array}$ & I \\
\hline & 23 & Hyperteleorbitism & $\begin{array}{l}\text { Bilateral fronto parietal atrophy, } \\
\text { ventricular enlargement, diffuse } \\
\text { subcortical atrophy }\end{array}$ & $\begin{array}{l}\text { Compensatory hydrocephalus, corpus } \\
\text { callosum hypoplasia, signs of } \\
\text { supratentorium and infratentorium } \\
\text { volumetric reduction }\end{array}$ \\
\hline & 24 & Hyperteleorbitism & I & $\begin{array}{l}\text { Enlargement of vascular spaces at basis } \\
\text { nucleus, ventricular asymmetry, corpus } \\
\text { callosum dysgenesis }\end{array}$ \\
\hline
\end{tabular}


is the main anomalous structure described in this condition. Fontaine et al. ${ }^{13}$ described 3 isolated cases with MFDH and corpus callosum agenesis. In a clinical follow-up of 8 patients, Pascual-Castroviejo et al. ${ }^{7}$ detected lipoma and calcification of faux in all of them and hypoplasia of the corpus callosum in brain CT. Guion-Almeida ${ }^{9}$ detected $8 / 100$ patients with corpus callosum agenesis. In an extensive review of the literature, and also adding personal cases, Gil-daSilva-Lopes and Maciel-Guerr $a^{3}$ obsened agenesis of this structure in 5/31 individuals and dysgenesis, in 4/31. These authors also described encephaloceles, ventricular anomalies, cortical atrophy and CNS calcifications.

Naidich et al. ${ }^{8}$ reported CNS findings of 11 individuals with MFDH detected, by computed CT of the crania in 10 and MRI in 1 of them. In this study, 5 patients with lipoma of the corpus callosum and 1 with calcification of faux and interhemispheric lipoma were observed. Gil-da-Silva-Lopes and Maciel-Guerra ${ }^{3}$ detected lipoma of corpus callosum in (2/31) patients.

Two of our patients had errors of migration detected by $\mathrm{CT}$ scan. This number had an increase when we used MRI (7/18). This kind of investigation also evidenced corpus callosum anomalies (agenesis/dysgenesis) in 8/18 individuals, ventricular anomalies $(8 / 18)$ and cerebellar hypoplasia in 3/18.

Cortical anomalies have been described in a group of 10 patients with frontonasal dysplasia, corpus callosum agenesis and mental retardation. In this group, MRI was performed in 8 patients (7M:1F). All the males had periventricular nodular heterotopia $(\mathrm{PNH})^{14}$. This author suggested that it would be an X-linked defect. PNH was also described by Dobyns et al. ${ }^{15}$, in 3 males affected by cerebellar hypoplasia, corpus callosum dysplasia, mental re $t$ a rdation and syndactyly; one of them had distal Xq duplication. Two other $\mathrm{u} n$ related males affected by PNH and mental retardation were described by Guerrini and Dobbyns ${ }^{16}$. Cerebellar hypoplasia detected in 3 individuals of this casuistry, reinforces the clinical suggestion of involvement of this structure in MFDH ${ }^{17}$.

The presence of several anatomic alterations of the CNS was similar in isolated cases and in MCA conditions. Considering the rarity of this disorder and the delineation of this study, this casuistry seems to be representative. Spite of it, it may be not enough for a conclusion among isolated and MCA forms of MFDH. In fact, these results could indicate a common embryologic damage or a sequence of events sec- ondarily to failure during the development of nasal capsule, as well. Thus, structural CNS anomalies and MFDH seem to have an intrinsic embryological relationship. These aspects should be taken into account during the clinical follow-up.

Finally, the use of MRI in this group of congenital defects would contribute for better characterization of CNS anatomical subtleness, such as migration errors.

Acknowledgements - The authors would thank the exceptional cooperation of the patients and their families, Hospital de Reabilitação Craniofacial (HRAC - "Centrinho" - USP) and Sociedade Brasileira de Pesquisa e Reabilitação de Anomalias Craniofaciais (SOBRAPAR, Campinas, SP). We also thanks Dr. Maria Leine Guion-Almeida (HRAC - "Centrinho" - USP) for her clinical opinion in some cases, and Drs. Vanda Maria Gimenes Gonçalves and Verônica A. Zamardi, from Departments of Neurology and Radiology (FCM/UNICAMP) for productive discussions.

\section{REFERENCES}

1. Sedano HO, Cohen MM Jr, Jirasek J, Gorlin RJ. Frontonasal dysplasia. J Pediatr 1970;76:906-913.

2. Sedano HO, Gorlin RJ. Frontonasal malformation as a field defect and in syndromic associations. Oral Surg 1988;65:704-710.

3. Gil-da-Silva-Lopes VL, Maciel-Guerra AT. A clinical study of 31 individuals with midline facial defects with hypertelorism (MFDH) and a guideline for follow-up. Clinn Dysmorphol J (2006, submitted)

4. Cohen Jr MM, Sedano HO, Gorlin RJ, Jirasek JE. Frontonasal dysplasia (median cleft face syndrome): comments on etiology and pathogenesis. Birth Defects. OAS 1971;7:117-119.

5. Cohen MM Jr. Malformations of the craniofacial region: evolutionary, embryonic, genetic and clinical perspectives. Am J Med Genet (Sem Med Genet) 2002;115:245-268

6. DeMyer W. The median cleft face syndrome. Differential diagnosis of cranium bifidum occultum, hypertelorism, and median cleft nose, lip, and palate. Neurology 1967;17:961- 971.

7. Pascual-Castroviejo I, Pascual-Pascual SI, Pérez-Higueras A. Frontonasal dysplasia and lipoma of the corpus callosum. Eur J Pediatr 1985; 144:66-71.

8. Naidich TP, Osborn RE, Bauer B, Naidich MJ. Median cleft face syn$\mathrm{d}$ rome: MRI and CT data from 11 children. J Comput Assist Tomogr 1988;12:57-64.

9. Guion-Almeida ML. Estudo genético clínico da disostose frontonasal. Dissertação. Bauru, 1991.

10. Giffoni SDA, Gonçalves VMG, Zanardi VA, Gil da Silva Lopes VL. Angular analysis of corpus callosum in 18 patients with frontonasal dysplasia. Arq Neuropsiquiatr 2004;62:195-198.

11. Conover, WJ. Practical nonparametric statistics. New York: John Wiley \& Sons, 1971.

12. Fleiss JL. Statistical methods for rates and proportions. New York: John Wiley and Sons, $2^{\text {nd }}$ ed., 1981.

13. Fontaine G, Walbaum R, Poupard B, et al. La dysplasie fronto-nasale (a propos de quatre observations). J Génét Hum 1983;31:351-365.

14. Guion-Almeida ML. Defeito de linha média facial e hipertelorismo. Tese. Campinas, 2000.

15. Dobyns WB, Guerrini R, Czapansky-Beilman DK, et al. Bilateral periventricular nodular heterotopia with mental retardation and syndactyly in boys: a new X-linked mental re ta rdation syndrome. Neurology 1997;49:1042-1047.

16. Guerrini R, Dobyns WB. Bilateral periventricular nodular heterotopia with mental retardation and frontonasal malformation. Neurology 1998;51:499-503.

17. Giffoni SDA, Gonçalves VMG, Zanardi VA, Gil-da-Silva-Lopes VL. Cerebellar involvement in midline facial defects with ocular hypertelorism. Cleft Palate Craniofac-J 2005;43:466-470. 